\title{
Public interest in spa therapy during the COVID-19 pandemic: analysis of Google Trends data among Turkey
}

\author{
Sinan Kardeş ${ }^{1}$ (iD \\ Received: 7 November 2020 / Revised: 28 December 2020 / Accepted: 5 January 2021 / Published online: 13 January 2021 \\ (C) ISB 2021
}

\begin{abstract}
In Turkey, spas are widely used and preferred by patients who are seeking relief from their disability and pain. The spa therapy program is partly reimbursed by the national health insurance system. The objective of the present study was to leverage Google Trends to elucidate the public interest in spas in Turkey during the COVID-19 pandemic. Google Trends was queried to analyze search trends within Turkey for the Turkish term representing a spa (i.e., kaplica) from January 01, 2016, to September 30, 2020. The relative search volume of "kaplica" was statistically significantly decreased in the March 15-May 30, 2020 (-73.04\%; $p<0.001)$; May 31-July 25, $2020(-41.38 \%$; $p<0.001)$; and July 26-September 19, $2020(-29.98 \%$; $p<0.001)$ periods compared to similar periods of preceding 4 years $(2016-2019)$. After June 1, 2020, the relative search volume was shown to have a moderate recovery, without reaching the level of 2016-2019. Public interest in spas showed an initial sharp decline between mid-March and May, with a moderate increase during the June-August period. This finding might be indicative of public preference in undertaking spa therapy during the COVID-19 period. In Turkey, spas might be used to increase places providing rehabilitation for both nonCOVID-19 patients and survivors of COVID-19 with long-term symptoms during the pandemic.
\end{abstract}

Keywords Google searches · Internet $\cdot$ Spa therapy $\cdot$ Balneotherapy $\cdot$ Hydrotherapy $\cdot$ Rehabilitation $\cdot$ COVID-19 $\cdot$ SARS-CoV-2

\section{Introduction}

At the end of 2019, a new coronavirus outbreak appeared in China. It was later identified as severe acute respiratory syndrome coronavirus 2 (SARS-CoV-2) and its illness identified as coronavirus disease 2019 (COVID-19). It has expanded from China throughout the world that led to the World Health Organization (2020) to declare COVID-19 a pandemic on March 11, 2020. On the same day, the health minister of Turkey has announced the first confirmed case of COVID-19 (Yağc1 et al. 2020). Then, the number of cases increased resulting in 314,433 cases and 7997 deaths in Turkey by the 27th of September 2020 (Republic of Turkey Ministry 2020).

The field of medicine has begun to integrate Google Trends as valuable epidemiologic data to monitor outbreaks and public interest (Eysenbach 2009; Mavragani and Ochoa 2019; Lu

Sinan Kardes

sinan.kardes@ istanbul.edu.tr

1 Department of Medical Ecology and Hydroclimatology, Istanbul Faculty of Medicine, Istanbul University, Istanbul, Turkey et al. 2018; Teng et al. 2017; Yang et al. 2017; Kardeș 2019a, 2019b; Kardeș and Kardeș 2019). It has been used to monitor several previous epidemics including influenza, Zika, and dengue (Lu et al. 2018; Teng et al. 2017; Yang et al. 2017) and public interest in several diseases including gout, bruxism, and psoriasis (Kardeș 2019a, 2019b; Kardeș and Kardeș 2019). In addition, during the COVID-19 pandemic, public interest in rheumatic diseases (Kardeș et al. 2020a) and several treatment modalities such as anti-rheumatic drugs (Kardeș et al. 2020b), surgical procedures of urology (Bhambhvani et al. 2020), knee arthroplasty (Landy et al. 2020), and facial plastic surgery (Dhanda et al. 2020) has been evaluated through analysis of Google Trends data.

Current management of COVID-19 consists of rehabilitation both in the acute period (in intensive care units or wards) and long-term period (after discharging from hospitals) (Ceravolo et al. 2020; Gutenbrunner et al. 2020; BarkerDavies et al. 2020; Liebl et al. 2020; Siddiq et al. 2020; Kurtaiş Aytür et al. 2020; Wang et al. 2020; Lopez et al. 2020). In Turkey, spas are widely used and preferred by patients who are seeking relief from their pain and disability (Kardeș et al. 2019). In addition, a spa therapy program 
prescribed by physicians is partly reimbursed by the national health insurance system and balneological modalities are integrated into several hospitals (Kardeș et al. 2019). In Turkey, spa therapy programs include balneotherapy, peloid therapy, aquatic exercises, physical therapy modalities, and exercise (Kardeș et al. 2019; Kardeş 2020a). Turkish spas might be used to increase places providing the rehabilitation of longterm COVID-19 patients, and non-COVID-19 patients, along with the hospital rehabilitation units, which are currently overwhelmed with acute rehabilitation of COVID-19 (Maccarone et al. 2020; Masiero et al. 2020a, b; Antonelli and Donelli 2020; Kardeș 2020b).

Therefore, the objective of the present study was to leverage Google Trends to elucidate the public interest in spas in Turkey during the COVID-19 pandemic.

\section{Materials and method}

The Google Trends data and its use in the field of medicine have been detailed in the previous articles (Mavragani and Ochoa 2019; Kardeș 2019a). Briefly, Google Trends is an open tool, which provides the relative volume of terms that people search in the Google engine. Google Trends allows for the specification of queries with the filters of time period and region. It automatically normalizes the proportion of query to all search queries on a range of 0 to 100 , in which higher scores represent more relative interest (Mavragani and Ochoa 2019; Kardeș 2019a).

The lay word of spa is "kaplica" in Turkish, and in Turkey, the public commonly uses it to refer to spa settings. On September 30, 2020, Google Trends was interrogated for the search term "kaplica." It was searched within Turkey from January 01, 2016, to September 30, 2020, using the "all categories" filter. Google Trends weekly data were downloaded for analysis.

The 11-week period (March 15-May 30, 2020), which coincided with strict lockdown and quarantine policies including the closure of spas, was compared to similar periods of preceding 4 years (2016-2019). Also, two following 8-week periods (May 31-July 25, 2020; July 26-September 19, 2020) were compared to similar periods of 2016-2019 to evaluate the interest after lockdown and quarantine lifted including the opening of spas on June 1, 2020. These comparisons were performed using generalized estimating equations with a gamma distribution in the Statistical Package for the Social Sciences (SPSS) version 21.0 (IBM Corporation, Armonk, NY). A time series plot was performed to illustrate the trends of spa searches in 2016-2019 and 2020 in Microsoft Excel version 14.3.7 (Microsoft Corporation, Redmond, WA). Statistical data presentation was informed by a recent review (Misra et al. 2020).

\section{Results}

The relative search volume of "kaplica" was statistically significantly decreased in the March 15-May 30, 2020 (73.04\%; $p<0.001)$; May 31-July 25, 2020 (- 41.38\%; $p<0.001)$; and July 26-September 19, 2020 (- 29.98\%; $p<0.001)$ periods compared to similar periods of preceding 4 years (2016-2019) (Table 1).

Figure 1 shows that the relative search volume of "kaplica" was lower in all weeks between March 15 and September 19, 2020, than the mean of the years 2016-2019. After June 1, 2020, the relative search volume was moderately increased; however, it did not reach to the level of 2016-2019 (Fig. 1).

\section{Discussion}

The study found a sharp decline in Google searches for the Turkish term representing spa between March 15 and May 30, 2020, period compared to similar periods in 2016-2019. After June 1,2020 , its relative popularity began to moderately increase; however, it was statistically lower during the May $31-$ July 25, 2020, and July 26-September 19, 2020, periods compared to similar periods of preceding 4 years.

The initial sharp decrease observed in the study was not surprising as this period coincides with strict lockdown and quarantine policies including the closure of spas. However, after lockdown/quarantine had lifted and spas had reopened on June 1,2020 , the public interest in spas has begun to gradually increase. This finding is interesting as it might be indicative of public preference in undertaking spa therapy during the COVID-19 period. In addition, it suggests that the safety measures implemented in spa resorts, which are issued by the Ministry of Health, ensured the trust of public in spa resorts to maintain COVID-19 infection control. These measures include checking body temperature/COVID-19 symptoms before entering the spas; the physical distancing of at least $1 \mathrm{~m}$; mask-wearing (except steamy environments); hand hygiene; avoid touching the face, eyes, mouth, and nose; and specific rules for cleaning, disinfecting, and ventilation of spas.

Current management of COVID-19 should include rehabilitation both in the acute period (in intensive care units or wards) and long-term period (after discharging from hospitals) (Ceravolo et al. 2020; Gutenbrunner et al. 2020; BarkerDavies et al. 2020; Liebl et al. 2020; Siddiq et al. 2020; Kurtaiș Aytür et al. 2020; Wang et al. 2020; Lopez et al. 2020). Acute period rehabilitation focuses on supporting respiratory functions and preventing the complications of immobilization/bed rest (Gutenbrunner et al. 2020; Liebl et al. 2020; Siddiq et al. 2020; Kurtaiș Aytür et al. 2020; Wang et al. 2020). In this period, rehabilitation interventions include positioning, respiration treatment, and early mobilization (Gutenbrunner et al. 2020; Liebl et al. 2020; Siddiq et al. 
Table 1 Relative search volume (RSV) of search term "kaplica" in Turkey during March 15September 19, 2020, and similar periods in 2016-2019

\begin{tabular}{lllll}
\hline March 15-May 30 & & & \\
& $2016-2019$ & 2020 & \% Change & $p$ \\
RSV of kaplica & $37.80(35.70$ to 40.02) & $10.18(8.64$ to 11.99) & $-73.04 \%$ & $<0.001$ \\
May 31-July 25 & & & \\
& $2016-2019$ & 2020 & $\%$ Change & $p$ \\
RSV of kaplica & $49.47(44.48$ to 55.02) & $29.00(25.44$ to 33.06) & $-41.38 \%$ & $<0.001$ \\
July 26-September 19 & & & \% Change & $p$ \\
RSV of kaplica & 2016-2019 & 2020 & $-29.98 \%$ & $<0.001$ \\
\hline
\end{tabular}

The word "kaplica" is the lay word of spa in Turkish. Data are presented as means (95\% confidence interval) (generalized estimating equations)
2020; Kurtaiş Aytür et al. 2020; Wang et al. 2020). Long-term period rehabilitation focuses on improving ongoing respiratory problems and restoration of physical disabilities either resulted by directly COVID-19 (its musculoskeletal/ neurological manifestations) (Ceravolo et al. 2020; Gutenbrunner et al. 2020; Barker-Davies et al. 2020; Liebl et al. 2020; Kurtaiş Aytür et al. 2020; Wang et al. 2020; Lopez et al. 2020) or intensive care stay (post-intensive care syndrome) (Ceravolo et al. 2020; Gutenbrunner et al. 2020), addressing psychological issues (e.g., depression and anxiety) as well (Gutenbrunner et al. 2020; Barker-Davies et al. 2020). The symptoms following discharge and rehabilitation needs of survivors of COVID-19 have been investigated in the previous three studies (Carfì et al. 2020; Garrigues et al. 2020; Halpin et al. 2020). Their findings show a high proportion of survivors of COVID-19 reported fatigue, dyspnea, joint pain, and psychological distress indicating the needs of rehabilitation to improve these symptoms (Carfi et al. 2020; Garrigues et al. 2020; Halpin et al. 2020).

In Turkey, 262 spa resorts are approved by the Health Ministry and a spa therapy program in these approved spas is reimbursed - except accommodation costs. These spas have experienced multidisciplinary rehabilitation teams (e.g., spa physicians, physical therapists, physiotherapists, and rehabilitation nurses) to provide and adjust the rehabilitation program to the individual patient's needs. Although spa therapy has yet no evidence specific to COVID-19, it and its interventions (e.g., balneotherapy, peloid therapy, aquatic exercises, and exercise) have been demonstrated beneficial in improving fatigue, dyspnea, pain, and depression/ anxiety, and in increasing quality of life of patients who have these symptoms, in many reviews and numerous clinical studies (Kamioka et al. 2020; Khaltaev et al. 2020; Munteanu et al. 2019; Baldi et al. 2015; Fioravanti et al. 2010, 2018; Rapoliené et al. 2020; Király et al. 2020; Gay et al. 2020; Bernetti et al. 2020; Varzaityte et al. 2020; Dilekçi et al. 2019, 2020; Eröksüz et al. 2020; Yuan et al. 2019; Cozzi et al. 2020; Gálvez et al. 2020; Corvillo et al. 2020; Pérez-Fernández et al. 2019; Peultier-Celli et al. 2019; Hanzel et al. 2019; Yücesoy et al. 2019; Özkuk and Dilekçi 2019; Masiero et al. 2020c; Tenti et al. 2020; Koçak et al. 2020; Özkuk and Uysal 2019; Cantista and Maraver 2020; Cheleschi et al. 2020; Özkuk and Ateș 2020; Min et al. 2020; Prossegger et al. 2019; Persiyanova-Dubrova et al. 2019). Interestingly, hypothetical
Fig. 1 Relative search volume (RSV) of search term "kaplica" in Turkey during March 15September 19, 2020, and similar periods in 2016-2019. The word "kaplica" is the lay word of spa in Turkish. Data of 2016-2019 are presented as means $(95 \%$ confidence interval) (generalized estimating equations)

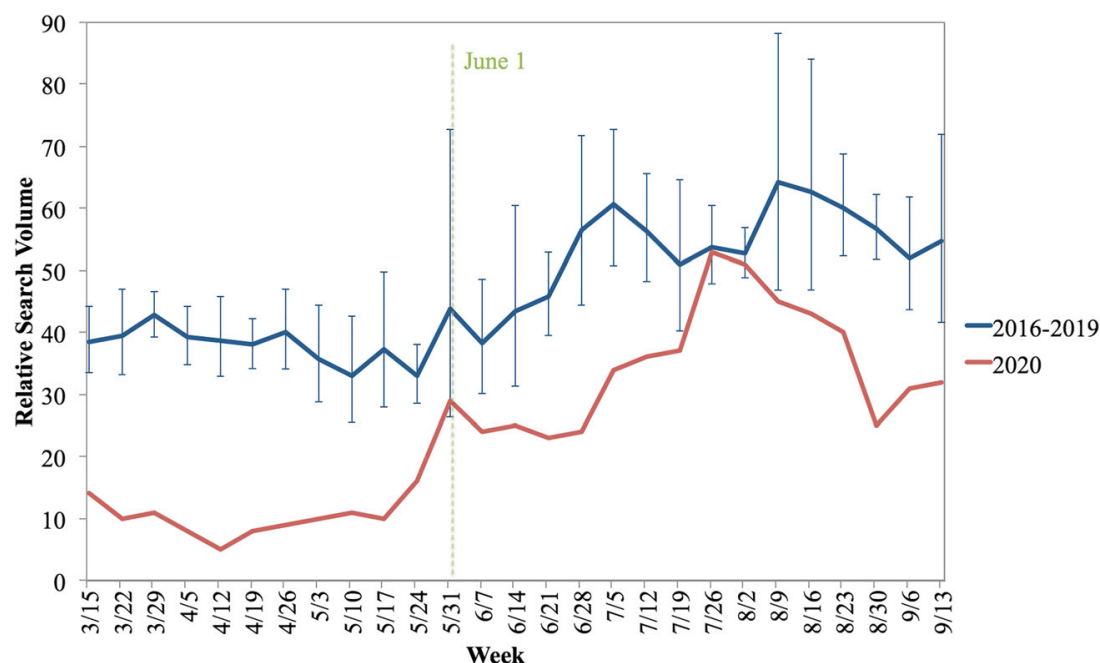


and theoretical backgrounds of using spas as rehabilitation facilities for post-COVID-19 patients have been discussed in several articles (Maccarone et al. 2020; Masiero et al. 2020a, b; Antonelli and Donelli 2020; Kardeș 2020b). Masiero et al. (2020a) and Kardeș et al. (2020b) provided clinical background and approach for spa therapy for post-COVID-19 patients. Antonelli and Donelli (2020) focused on spa therapy for respiratory rehabilitation for post-COVID-19 patients. Maccarone et al. (2020) and Masiero et al. (2020b) overviewed the effects of balneotherapy on human immune function during the COVID-19 era. Although all these previous articles explored the hypothetical and theoretical aspects and perspectives for spa therapy during the pandemic, clinical studies investigating the efficacy of spa therapy program in COVID-19 survivors with long-term symptoms are required to provide evidence regarding its use and benefits.

\section{Limitations}

This study has some limitations. Google Trends only provides data of Google searches; however, in Turkey, more than $75 \%$ of all internet queries are searched through the Google search engine. Therefore, its data are likely representative of all Internet queries. Moreover, Google Trends only provides populationlevel data, so the public interest could not be assessed by dividing the population into subgroups (i.e., age, sex). Additionally, the present study does not provide any evidence on the possible use of spas in the rehabilitation of long-term COVID-19 patients; therefore, the results should only be interpreted as the general public interest in spas during the pandemic.

\section{Conclusion}

Public interest in spas showed an initial sharp decline between mid-March and May, with a moderate increase during the June-August period. This finding might be indicative of public preference in undertaking spa therapy during the COVID-19 period. In Turkey, spas might be used to increase places providing rehabilitation for both non-COVID-19 patients and survivors of COVID19 with long-term symptoms during the pandemic.

\section{Compliance with ethical standards}

Conflict of interest The author declares no competing interests.

Ethics approval Not applicable.

\section{References}

Antonelli M, Donelli D (2020) Respiratory rehabilitation for postCOVID19 patients in spa centers: first steps from theory to practice. Int J Biometeorol 64:1811-1813. https://doi.org/10.1007/s00484020-01962-5

Baldi S, Pinna GD, Bruschi C, Caldara F, Maestri R, Dacosto E, Rezzani A, Popovich E, Bellinzona E, Crotti P, Montemartini S, Fracchia C (2015) Medicinal clays improve the endurance of loaded inspiratory muscles in COPD: a randomized clinical trial of nonpharmacological treatment. Int J Chron Obstruct Pulmon Dis 10:2235-2248. https://doi.org/10.2147/COPD.S87999

Barker-Davies RM, O'Sullivan O, Senaratne KPP, Baker P, Cranley M, Dharm-Datta S, Ellis H, Goodall D, Gough M, Lewis S, Norman J, Papadopoulou T, Roscoe D, Sherwood D, Turner P, Walker T, Mistlin A, Phillip R, Nicol AM, Bennett AN, Bahadur S (2020) The Stanford Hall consensus statement for post-COVID-19 rehabilitation. Br J Sports Med 54:949-959. https://doi.org/10.1136/ bjsports-2020-102596

Bernetti A, Mangone M, Alviti F, Paolucci T, Attanasi C, Murgia M, Di Sante L, Agostini F, Vitale M, Paoloni M (2020) Spa therapy and rehabilitation of musculoskeletal pathologies: a proposal for best practice in Italy. Int J Biometeorol 64:905-914. https://doi.org/10. 1007/s00484-019-01731-z

Bhambhvani HP, Tijerina JD, Parham MJ, Greenberg DR, Eisenberg ML (2020) Public interest in elective urologic procedures in the COVID19 pandemic: a Google Trends analysis. Urol Pract 7:496-501. https://doi.org/10.1097/UPJ.0000000000000179

Cantista P, Maraver F (2020) Balneotherapy for knee osteoarthritis in S. Jorge: a randomized controlled trial. Int J Biometeorol 64:10271038. https://doi.org/10.1007/s00484-020-01911-2

Carfi A, Bernabei R, Landi F, Gemelli Against COVID-19 Post-Acute Care Study Group (2020) Persistent symptoms in patients after acute COVID-19. JAMA 324:603-605. https://doi.org/10.1001/jama. 2020.12603

Ceravolo MG, Arienti C, de Sire A, Andrenelli E, Negrini F, Lazzarini SG, Patrini M, Negrini S, International Multiprofessional Steering Committee of Cochrane Rehabilitation REH-COVER action (2020) Rehabilitation and COVID-19: the Cochrane Rehabilitation 2020 rapid living systematic review. Eur J Phys Rehabil Med 56:642651. https://doi.org/10.23736/S1973-9087.20.06501-6

Cheleschi S, Gallo I, Tenti S (2020) A comprehensive analysis to understand the mechanism of action of balneotherapy: why, how, and where they can be used? Evidence from in vitro studies performed on human and animal samples. Int J Biometeorol 64:1247-1261. https://doi.org/10.1007/s00484-020-01890-4

Corvillo I, Armijo F, Álvarez-Badillo A, Armijo O, Varela E, Maraver F (2020) Efficacy of aquatic therapy for neck pain: a systematic review. Int J Biometeorol 64:915-925. https://doi.org/10.1007/ s00484-019-01738-6

Cozzi F, Galozzi P, Ciprian L, Zanatta E, Polito P, Oliviero F, Carrara M, Punzi L (2020) Mud-bath treatment of seronegative spondyloarthritis: experience at the Euganean Thermal Area. Int J Biometeorol 64:937-941. https://doi.org/10.1007/s00484-01901761-7

Dhanda AK, Leverant E, Leshchuk K, Paskhover B (2020) A Google Trends analysis of facial plastic surgery interest during the COVID19 pandemic. Aesthet Plast Surg 44:1378-1380. https://doi.org/10. 1007/s00266-020-01903-y

Dilekçi E, Özkuk K, Kaki B (2019) Effect of balneotherapy on pain and fatigue in elderly with knee osteoarthritis receiving physical therapy: a randomized trial. Int J Biometeorol 63:1555-1568. https://doi.org/ 10.1007/s00484-019-01768-0

Dilekçi E, Özkuk K, Kaki B (2020) The short-term effects of balneotherapy on pain, disability and fatigue in patients with chronic 
low back pain treated with physical therapy: a randomized controlled trial. Complement Ther Med 54:102550. https://doi.org/10. 1016/j.ctim.2020.102550

Eröksüz R, Erol Forestier FB, Karaaslan F, Forestier R, İșsever H, Erdoğan N, Karagülle MZ, Dönmez A (2020) Comparison of intermittent and consecutive balneological outpatient treatment (hydrotherapy and peloidotherapy) in fibromyalgia syndrome: a randomized, single-blind, pilot study. Int J Biometeorol 64:513-520. https:// doi.org/10.1007/s00484-019-01838-3

Eysenbach G (2009) Infodemiology and infoveillance: framework for an emerging set of public health informatics methods to analyze search, communication and publication behavior on the Internet. J Med Internet Res 11:e11. https://doi.org/10.2196/jmir.1157

Fioravanti A, Iacoponi F, Bellisai B, Cantarini L, Galeazzi M (2010) Short- and long-term effects of spa therapy in knee osteoarthritis. Am J Phys Med Rehabil 89:125-132

Fioravanti A, Manica P, Bortolotti R, Cevenini G, Tenti S, Paolazzi G (2018) Is balneotherapy effective for fibromyalgia? Results from a 6-month double-blind randomized clinical trial. Clin Rheumatol 37: 2203-2212. https://doi.org/10.1007/s10067-018-4117-z

Gálvez I, Torres-Piles S, Ortega E (2020) Effect of mud-bath therapy on the innate/inflammatory responses in elderly patients with osteoarthritis: a discussion of recent results and a pilot study on the role of the innate function of monocytes. Int J Biometeorol 64:927-935. https://doi.org/10.1007/s00484-019-01748-4

Garrigues E, Janvier P, Kherabi Y, Le Bot A, Hamon A, Gouze H, Doucet L, Berkani S, Oliosi E, Mallart E, Corre F, Zarrouk V, Moyer JD, Galy A, Honsel V,Fantin B, Nguyen Y (2020) Postdischarge persistent symptoms and health-related quality of life after hospitalization for COVID-19. J Infect 81:e4-e6. https://doi.org/10. 1016/j.jinf.2020.08.029

Gay C, Guiguet-Auclair C, Coste N, Boisseau N, Gerbaud L, Pereira B, Coudeyre E (2020) Limited effect of a self-management exercise program added to spa therapy for increasing physical activity in patients with knee osteoarthritis: a quasi-randomized controlled trial. Ann Phys Rehabil Med 63:181-188. https://doi.org/10.1016/j. rehab.2019.10.006

Gutenbrunner C, Stokes EK, Dreinhöfer K, Monsbakken J, Clarke S, Côté P, Urseau I, Constantine D, Tardif C, Balakrishna V, Nugraha B (2020) Why rehabilitation must have priority during and after the COVID-19-pandemic: a position statement of the Global Rehabilitation Alliance. J Rehabil Med 52:jrm00081. https://doi.org/10.2340/16501977-2713

Halpin SJ, McIvor C, Whyatt G, Adams A, Harvey O, McLean L, Walshaw C, Kemp S, Corrado J, Singh R, Collins T, O'Connor RJ, Sivan M (2020) Postdischarge symptoms and rehabilitation needs in survivors of COVID-19 infection: a cross-sectional evaluation. J Med Virol 93:1013-1022. https://doi.org/10.1002/jmv. 26368

Hanzel A, Berényi K, Horváth K, Szendi K, Németh B, Varga C (2019) Evidence for the therapeutic effect of the organic content in Szigetvár thermal water on osteoarthritis: a double-blind, randomized, controlled clinical trial. Int J Biometeorol 63:449-458. https:// doi.org/10.1007/s00484-019-01676-3

Kamioka H, Nobuoka S, liyama J (2020) Overview of systematic reviews with meta-analysis based on randomized controlled trials of balneotherapy and spa therapy from 2000 to 2019. Int J Gen Med 13:429-442. https://doi.org/10.2147/IJGM.S261820

Kardeș S (2019a) Seasonal variation in the internet searches for gout: an ecological study. Clin Rheumatol 38:769-775. https://doi.org/10. 1007/s10067-018-4345-2

Kardeș S (2019b) Seasonal variation in the internet searches for psoriasis. Arch Dermatol Res 311:461-467. https://doi.org/10.1007/s00403019-01921-0
Kardeș S (2020a) Pathophysiological mechanisms of balneotherapy with potential implications for central Asian spas and sanatoriums. Cent Asian J Med Hypotheses Ethics. (Accepted)

Kardeş S (2020b) Spa therapy (balneotherapy) for rehabilitation of survivors of COVID-19 with persistent symptoms. Med Hypotheses 146:110472. https://doi.org/10.1016/j.mehy.2020.110472

Kardeș S, Kardeș E (2019) Seasonality of bruxism: evidence from Google Trends. Sleep Breath 23:695-701. https://doi.org/10.1007/ s11325-019-01787-6

Kardeș S, Karagülle M, Geçmen İ, Adıgüzel T, Yücesoy H, Karagülle MZ (2019) Outpatient balneological treatment of osteoarthritis in older persons: a retrospective study. Z Gerontol Geriatr 52:164171. https://doi.org/10.1007/s00391-018-1370-3

Kardeş S, Kuzu AS, Raiker R, Pakhchanian H, Karagülle M (2020a) Public interest in rheumatic diseases and rheumatologist in the United States during the COVID-19 pandemic: evidence from Google Trends. Rheumatol Int. https://doi.org/10.1007/s00296020-04728-9

Kardeș S, Kuzu AS, Pakhchanian H, Raiker R, Karagülle M (2020b) Population-level interest in anti-rheumatic drugs in the COVID-19 era: insights from Google Trends. Clin Rheumatol. https://doi.org/ 10.1007/s10067-020-05490-w

Khaltaev N, Solimene U, Vitale F, Zanasi A (2020) Balneotherapy and hydrotherapy in chronic respiratory disease. J Thorac dis 12:44594468. https://doi.org/10.21037/jtd-gard-2019-009

Király M, Kővári E, Hodosi K, Bálint PV, Bender T (2020) The effects of Tiszasüly and Kolop mud pack therapy on knee osteoarthritis: a double-blind, randomised, non-inferiority controlled study. Int J Biometeorol 64:943-950. https://doi.org/10.1007/s00484-01901764-4

Koçak FA, Kurt EE, Milletli Sezgin F, Șaș S, Tuncay F, Erdem HR (2020) The effect of balneotherapy on body mass index, adipokine levels, sleep disturbances, and quality of life of women with morbid obesity. Int J Biometeorol 64:1463-1472. https://doi.org/10.1007/ s00484-020-01924-x

Kurtaiș Aytür Y, Köseoğlu BF, Özyemișçi Tașkıran Ö, Ordu-Gökkaya NK, Ünsal Delialioğlu S, Sonel Tur B, Sarıkaya S, Șirzai H, Tekdemir Tiftik T, Alemdaroğlu E, Ayhan FF, Duyur Çakıt BD, Genç A, Gündoğdu İ, Güzel R, Demirbağ Karayel D, Bilir Kaya B, Öken Ö, Özdemir H, Soyupek F, T1kız C (2020) Pulmonary rehabilitation principles in SARS-COV-2 infection (COVID-19): a guideline for the acute and subacute rehabilitation. Turk J Phys Med Rehabil 66:104-120. https://doi.org/10.5606/tttrd.2020.6444

Landy DC, Chalmers BP, Utset-Ward TJ, Ast MP (2020) Public interest in knee replacement fell during the onset of the COVID-19 pandemic: a Google Trends analysis. HSS J 16:24-28. https://doi.org/10. 1007/s11420-020-09794-0

Liebl ME, Gutenbrunner C, Glaesener JJ, Schwarzkopf S, Best N, Lichti G, Kraft E, Krischak G, Reißhauer A (2020) Early rehabilitation in COVID-19-best practice recommendations for the early rehabilitation of COVID-19 patients. Physikalische Medizin, Rehabilitationsmedizin, Kurortmedizin 30:129-134. https://doi. org/10.1055/a-1162-4919

Lopez M, Bell K, Annaswamy T, Juengst S, Ifejika N (2020) COVID-19 guide for the rehabilitation clinician: a review of nonpulmonary manifestations and complications. Am J Phys Med Rehabil 99: 669-673. https://doi.org/10.1097/PHM.0000000000001479

Lu FS, Hou S, Baltrusaitis K, Shah M, Leskovec J, Sosic R, Hawkins J, Brownstein J, Conidi G, Gunn J, Gray J, Zink A, Santillana M (2018) Accurate influenza monitoring and forecasting using novel internet data streams: a case study in the Boston Metropolis. JMIR Public Health Surveill 4:e4. https://doi.org/10.2196/publichealth. 8950

Maccarone MC, Magro G, Solimene U, Masiero S (2020) The effects of balneotherapy on human immune gunction: should baths and mud applications have a role during Covid-19 pandemic?. Bulletin of 
rehabilitation medicine. 3:22-24. https://doi.org/10.38025/20781962-2020-97-3-22-24

Masiero S, Maccarone MC, Agostini F (2020a) Health resort medicine can be a suitable setting to recover disabilities in patients tested negative for COVID-19 discharged from hospital? A challenge for the future Int J Biometeorol 64:1807-1809. https://doi.org/10.1007/ s00484-020-01947-4

Masiero S, Maccarone MC, Magro G (2020b) Balneotherapy and human immune function in the era of COVID-19. Int J Biometeorol 64: 1433-1434. https://doi.org/10.1007/s00484-020-01914-z

Masiero S, Litwocenko S, Agostini F; On behalf section of Rehabilitation in Environmental Thermal for Italian Society of Physical Medicine and Rehabilitation (2020c) Rehabilitation in an Italian thermal setting: a new therapeutic strategy for patients with musculoskeletal disability-the results of an Italian survey. Int J Biometeorol 64: 951-954. https://doi.org/10.1007/s00484-019-01765-3

Mavragani A, Ochoa G (2019) Google Trends in infodemiology and infoveillance: methodology framework. JMIR Public Health Surveill 5:e13439. https://doi.org/10.2196/13439

Min KJ, Choi H, Tae BS, Lee MG, Lee SJ, Hong KD (2020) Short-term benefits of balneotherapy for patients with chronic pelvic pain: a pilot study in Korea. J Obstet Gynaecol 40:520-525. https://doi. org/10.1080/01443615.2019.1631771

Misra DP, Zimba O, Gasparyan AY (2020) Statistical data presentation: a primer for rheumatology researchers. Rheumatol Int. https://doi.org/ 10.1007/s00296-020-04740-Z

Munteanu C, Munteanu D, Hoteteu M, Dogaru G (2019) Balneotherapymedical, scientific, educational and economic relevance reflected by more than 250 articles published in Balneo Research Journal. Balneo Research Journal 10:174-203. https://doi.org/10.12680/ balneo.2019.257

Özkuk K, Ateș Z (2020) Balneotherapy in the treatment of chronic shoulder pain: a randomized controlled clinical trial. Altern Ther Health Med 26:18-24

Özkuk K, Dilekçi E (2019) The effects of balneotherapy in elderly patients with chronic low back pain treated with physical therapy: a pilot study. J Ist Faculty Med 82:186-192. https://doi.org/10.26650/ IUITFD.2019.0025

Özkuk K, Uysal B (2019) Is the duration of spa cure treatment important in knee osteoarthritis? A randomized controlled study. Complement Med Res 26:258-264. https://doi.org/10.1159/000498890

Pérez-Fernández MR, Calvo-Ayuso N, Martínez-Reglero C, SalgadoBarreira Á, Muiño López-Álvarez JL (2019) Efficacy of baths with mineral-medicinal water in patients with fibromyalgia: a randomized clinical trial. Int J Biometeorol 63:1161-1170. https://doi.org/ 10.1007/s00484-019-01729-7

Persiyanova-Dubrova AL, Badalov NG, Marfina TV, Rachin AP (2019) Balneotherapy and modification of risk factors in cardiovascular disease prevention programs. Vopr Kurortol Fizioter Lech Fiz Kult 96:49-57. https://doi.org/10.17116/kurort20199604149

Peultier-Celli L, Lion A, Chary-Valckenaere I, Loeuille D, Zhang Z, Rat AC, Gueguen R, Paysant J, Perrin PP (2019) Comparison of highfrequency intensive balneotherapy with low-frequency balneotherapy combined with land-based exercise on postural control in symptomatic knee osteoarthritis: a randomized clinical trial. Int J Biometeorol 63:1151-1159. https://doi.org/10.1007/s00484019-01727-9

Prossegger J, Huber D, Grafetstätter C, Pichler C, Weisböck-Erdheim R, Iglseder B, Wewerka G, Hartl A (2019) Effects of moderate mountain hiking and balneotherapy on community-dwelling older people: a randomized controlled trial. Exp Gerontol 122:74-84. https://doi.org/10.1016/j.exger.2019.04.006

Rapolienè L, Razbadauskas A, Mockevičienė D, Varžaitytė L, Skarbalienè A (2020) Balneotherapy for musculoskeletal pain: does the mineral content matter? Int J Biometeorol 64:965-979. https:// doi.org/10.1007/s00484-019-01800-3

Republic of Turkey Ministry, Covid-19 information page. https:// covid19.saglik.gov.tr/. Accessed 28 September 2020

Siddiq MAB, Rathore FA, Clegg D, Rasker JJ (2020) Pulmonary rehabilitation in COVID-19 patients: a scoping review of current practice and its application during the pandemic. Turk J Phys Med Rehab 66: 480-494. https://doi.org/10.5606/tttrd.2020.6889

Teng Y, Bi D, Xie G, Jin Y, Huang Y, Lin B, An X, Feng D, Tong Y (2017) Dynamic forecasting of Zika epidemics using Google Trends. PLoS One 12:e165085. https://doi.org/10.1371/journal. pone. 0165085

Tenti S, Manica P, Cheleschi S, Fioravanti A (2020) Sulfurous-arsenicalferruginous balneotherapy for osteoarthritis of the hand: results from a retrospective observational study. Int J Biometeorol 64:15611569. https://doi.org/10.1007/s00484-020-01937-6

Varzaityte L, Kubilius R, Rapoliene L, Bartuseviciute R, Balcius A, Ramanauskas K, Nedzelskiene I (2020) The effect of balneotherapy and peloid therapy on changes in the functional state of patients with knee joint osteoarthritis: a randomized, controlled, single-blind pilot study. Int J Biometeorol 64:955-964. https://doi.org/10.1007/ s00484-019-01785-z

Wang TJ, Chau B, Lui M, Lam GT, Lin N, Humbert S (2020) Physical medicine and rehabilitation and pulmonary rehabilitation for COVID-19. Am J Phys Med Rehabil 99:769-774. https://doi.org/ 10.1097/PHM.0000000000001505

World Health Organization announces COVID-19 outbreak a pandemic. https://www.euro.who.int/en/health-topics/health-emergencies/ coronavirus-covid-19/news/news/2020/3/who-announces-covid19-outbreak-a-pandemic/. Accessed September 12, 2020

Yağcı İ, Sarıkaya S, Ayhan FF, Bahsi A, Bilir Kaya B, Erhan B, Dündar Ahi E, Okan S, Özkan Y, Korkmaz MD, Yakși E, Demirbağ Kabayel D, Özdemir H, Kayalar G, Çelik C, Kesiktaș FN, Cağlar Yagc1 H, Altan L (2020) The effects of COVID-19 on physical medicine and rehabilitation in Turkey in the first month of pandemic. Turk J Phys Med Rehabil 66:244-251. https://doi.org/10.5606/ tftrd.2020.6800

Yang S, Kou SC, Lu F, Brownstein JS, Brooke N, Santillana M (2017) Advances in using Internet searches to track dengue. PLoS Comput Biol 13:e1005607. https://doi.org/10.1371/journal.pcbi.1005607

Yuan D, Yu ZX, Wang W, Chen Y (2019) Head-out immersion in natural thermal mineral water for the management of hypertension: a review of randomized controlled trials. Int J Biometeorol 63:1707-1718. https://doi.org/10.1007/s00484-019-01780-4

Yücesoy H, Geçmen İ, Adıgüzel T, Karagülle M, Karagülle MZ (2019) Efficacy of balneological outpatient treatment (hydrotherapy and peloidotherapy) for the management of chronic low back pain: a retrospective study. Int J Biometeorol 63:351-357. https://doi.org/ 10.1007/s00484-018-01668-9

Publisher's note Springer Nature remains neutral with regard to jurisdictional claims in published maps and institutional affiliations. 